\title{
PEMANFAATAN EKSTRAK BUAH LAMBAI-LAMBAI UNTUK MENGOBATI PENYAKIT MAS PADA IKAN NILA (OREOCHROMIS NILOTIUS)
}

\author{
Leni Handayani \\ Program Studi Budidaya Perairan Fakultas Pertanian Universitas Darwan Ali Kampus Kuala Pembuang \\ J1. Kihajar Dewantara, Kuala Pembuang Kabupaten Seruyan, Kode Pos74212 \\ E-mail : syanala81@gmail.com
}

\begin{abstract}
ABSTRAK
Penelitiaan ini bertujuan utuk mengetahui pengaruh ekstrak buah lambai-lambai untuk mengobati penyakit MAS pada ikan nila (Orechromis niloticus). Penelitiaan ini menggunakan Rancangan Acak Lengkap (RAL) dengan 4 perlakuan dan 3 ulangan. Perlakuan yang digunakan adalah melalui perendaman selama 48 jam dengan konsentrasi A (0 ppm), B (50 ppm), C (100 ppm) dan D (150 ppm). Ikan nila yang digunakan sebanyak 120 ekor dengan ukuran $10-13 \mathrm{~cm}$. parameter yang diamati gejala klinis, proses penyembuhan luka, respon ikan, kelangsungan hidup dan kualitas air. Gejala klinis, proses penyembuhan luka, respon ikan dan kualitas air dianalisis secara deskriptif. Penelitiaan ini dilaksanakan pada bulan November - Desember 2016.

Hasil penelitiaan menunjukan bahwa pemberiaan ekstrak lambai-lambai dengan metode perendaman selama 48 jam pada konsentrasi 100 ppm mengalami proses penyembuhan lebih cepat dibanding perlakuan lain, pada konsentrasi ini proses penyembuhan mulai terjadi pada hari ke-4 dan terus mengalami proses penyembuhan yang signifikan sampai akhir masa pemeliharaan dengan rata-rata kelangsungan hidup ikan sebesar 83,33\% dan menujukan respon pakan pada hari ke-6 dan hari ke-5 untuk respon kejutan. Kualitas air selama masa pemeliharaan masih dapat ditoleransi oleh ikan uji.
\end{abstract}

Kata Kunci: Aeromonas, ekstrak, lambai-lambai, MAS

\section{PENDAHULUAN}

Ikan nila (Oreochromis niloticus) di Kabupaten Seruyan merupakan salah satu ikan yang mempunyai harga relatif stabil dan peminatnya cukup banyak. Banyaknya permintaan pasar terhadap komoditas ini membuat budidaya ikan nila banyak dibudidayakan ditempat sekitar. Budidaya ini tidak lepas dari masalah salah satu nya adalah serangan penyakit.

Salah satu penyakit yang sering menyerang ikan nila adalah Motile Aeromonas septicemia (MAS) yaitu penyakit yang disebabkan oleh bakteri A. hydrophila. Bakteri ini sering menyerang ikan air tawar dan dapat menginfeksi ikan pada semua ukuran yang dapat menyebabkan kematian hingga mencapai $80 \%$, sehingga mengakibatkan kerugian yang sangat besar (Sanoesi, 2008).

Selama ini para petani banyak menggunakan berbagai bahan-bahan kimia maupun antibiotik lainnya yang harganya relatif mahal. Penggunaan obat dan antibiotik untuk mengontrol penyakit bakteri dapat menimbulkan masalah yaitu mempengaruhi dan mampu membunuh organisme bukan sasaran serta timbulnya pathogen yang resisten terhadap obat-obatan dan antibiotik, menimbulkan residu pada daging ikan, mempengruhi pertumbuhan dan menimbulkan pencemaran lingkungan (Nitimulyo, 1996 dalam Aisyah, 2013).
Berkaitan dengan permasalahan tersebut, perlu ada alternatif bahan obat yang lebih aman yang dapat digunakan dalam pengobatan penyakit ikan. Salah satu alternatifnya adalah dengan menggunakan tumbuhan alami yaitu lambai-lambai.Lambai-lambai (Cayratia trifona) merupakan tanaman liar yang banyak ditemukan disekitar jalan di daerah Kuala Pembuang Kabupaten Seruyan. Tanaman ini belum termanfaatkan secara optimal oleh masyarakat sekitar. Pemanfaatannya hanya sebatas konsumsi untuk penambah pembuatan sambel.

Penelitiaan ini bertujuan untuk mengetahui pengaruh ekstrak buah lambai-lambai untuk mengobati penyakit MAS pada ikan Nila (Orechromis niloticus).

\section{RUANG LINGKUP PENELITIAN}

Dalam penelitiaan ini permasalahan mencakup:

1. Belum dimanfaatkannya tumbuhan lambai-lambai di Kabupaten Seruyan

2. Masi banyak petani ikan yang menggunakan bahan kimia untuk mengobati penyakit ikan

3. Batasan -batasan penelitiaan ini adalah pengamatan bakteri Aeromonas hydrophila hanya pada ikan nila (Oreochromis niloticus) dan hanya buah lambai-lambai saja yang digunakan.

4. Rencana hasil yang didapat pada penelitiaan ini adalah diharapkan akan adanya bahan alami yang 
digunakan untuk mengobati serangan Aeromonas hydrophyla sehingga tidak berdampak terhadap lingkungan.

\section{BAHAN DAN METODE}

Ikan uji yang digunakan dalam penelitiaan ini adalah benih ikan nila sebanyak 120 ekor dengan ukuran 10-13 cm/ekor dengan kepadatan 10 ekor/bak. Buah lambailambai yang digunakan diperoleh di Kuala Pembuang Kabupaten Seruyan. Isolat bakteri Aeromonas hydrophila dan pakan komersil.

Bahan Penelitiaan ini dilaksanakan pada bulan November - Desember 2016. Metode yang digunakan adalah Rancangan Acak Lengkap (RAL) dengan 4

perlakuan dan 3 ulangan. Perlakuan yang digunakan adalah melalui perendaman selama 48 jam dengan konsentrasi A ( 0 ppm), B (50 ppm), C (100 ppm) dan D $(150 \mathrm{ppm})$. Parameter yang diamati yaitu gejala klinis, penyembuhan luka, respon ikan, kelangsungan hidup dan kualitas air. Gejala klinis, proses pemulihan dan kualitas air dianalisis secara deskriptif sedangkan pengaruh perlakuan perendaman ekstrak lambai-lambai terhadap kelangsungan hidup dianalisi menggunakan anova dan jika ada perbedaan nyata maka dilanjutan dengan uji berganda Duncan (Gasperz, 2006).

1. Gejala Klinis dan Proses Penyembuhan Luka

Pengamatan gejala klinis dilakukan setiap hari setelah ikan diinfeksi dengan bakteri Aeromonas hydrophila. Pengukuran diameter klinis dilakukan dengan mengukur luas kelainan klinis dengan menggunakan penggaris, kemudian data yang telah diperoleh diberi skor. Nilai skor kelainan klinis yang menunjukan tingkat keparahan infeksi dilakukan dengan ketentuaan sebagai berikut (modifikasi dari Abdullah, 2008) :

$\begin{array}{lll}\mathrm{Sm} & =\text { Ikan sembuh } & \text { Nilai skor }=0 \\ \mathrm{~N} & \text { = Ikan normal } & \text { Nilai skor }=0 \\ \mathrm{R} & \text { = Ikan radang } & \text { Nilai skor }=1 \\ \mathrm{Hm} & =\text { Ikan haemoragi } & \text { Nilai skor }=2 \\ \mathrm{Nk} & =\text { Ikan Nekrosis } & \text { Nilai skor }=3 \\ \mathrm{~T} & =\text { Ikan tukak } & \text { Nilai skor }=4 \\ \mathrm{M} & =\text { Ikan mati } & \text { Nilai skor }=5\end{array}$

Rumus perhitungan persentase penyembuhan luka (sartika, 2011) adalah (1):

$$
\Delta \mathrm{x}=\left[\frac{\text { DLB }- \text { DLK }}{\text { DLB }} \times 100 \%\right] \times \frac{1}{t}
$$

\footnotetext{
Keterangan (1)

$\Delta x \quad$ : penyembuhan luka (\% hari )

DLB : diameter luka besar $(\mathrm{cm})$

DLK : diameter luka kecil ( $\mathrm{cm})$

$\mathrm{t} \quad$ : lama penyembuhan ( hari )
}

2. Kelangsungan Hidup (Survival Rate)

Kelangsungan hidup dihitung dengan menggunakan rumus (Effendi, 2002) yaitu (2)

$$
S R=\frac{N t}{N o} \times 100 \%
$$

Keterangan (2) :

SR : Derajat kelangsungan hidup (\%)

$\mathrm{Nt} \quad$ : Jumlah ikan hidup pada akhir pemeliharaan (ekor)

No : Jumlah ikan pada awal pemeliharaan (ekor)

3. Respon ikan

Pengamatan respon dilakukan dengan 2 pengamatan, yaitu:

1) Respon terhadap Pakan

Respon pakan diamati dengan melihat reaksi ikan uji pada saat pemberiaan pakan dan sisa pakan yang tersisa.

2) Respon terhadap kejutan

Pengamatan terhadap kejutan dilakukan dengan cara menepuk dinding media pemeliharaan pada bagian luar.

Pengamatan ini dilakukani setiap hari.selama masa pemeliharaan.

4. Kualitas air

Pengukuran parameter kualtas air yang meliputi suhu, $\mathrm{DO}, \mathrm{pH}$ dan $\mathrm{NH}_{3}$ dilakukan pada awal dan akhir penelitiaan.

\section{HASIL DAN PEMBAHASAN}

Dijabarkan hasil penelitian ini, dimana pembahasan difokuskan pada gejala klinis dan proses penyembuhan lluka, kelangsunga hidup, sampai kualitas air.

\subsection{Gejala Klinis dan Proses Penyembuhan Luka}

Rangcangan Gejala Klinis dan proses penyembuhan luka. Berdasarkan hasil pengamatan yang telah diakukan gejala klinis yang terjadi pada ikan nila (Oreochromis niloticus) terjadi setelah 48 jam pasca infeksi bakteri. Gejala klinis yang ditimbulkan yaitu adanya radang disekitar area penyuntikan, haemoragi, tukak bahkan adanya kematiaan. Gejala klinis yang dilihatkan oleh hewan uji ini sejalan dengan pendapat Normalina, 2007 dalam Kurniawan (2010), menyatakan bahwa gejala klinis pada ikan catfish yang timbul setelah penginfeksian Aeromonas hydrophilla adalah mengalami radang pada daerah penyuntikan, kemudian berkembang menjadi haemoragi dan tukak.

Proses penyembuhan luka pada perlakuan C mulai terjadi pada hari ke-4 dan proses penyembuhan pada hari ke-6 sampai hari ke-15 untuk perlakuan B dan D sedangkan perlakuan A proses penyembuhan luka terjadi pada hari ke-10. Indikator penyembuhan luka dilihat dari diameter tukak yang awalnya besar berubah menjadi kecil dan dari skor rata-rata gejala klinis pada setiap perlakuan. Penyembuhan luka diduga disebabkan karena adanya bahan aktif (allisin) dari ekstrak bahan alami yang masuk ke dalam tubuh ikan hingga mampu meningkatkan ketahanan tubuh terhadap serangan patogen bakteri Aeromonas hydrophilla 
Tabel 1. Persentase Penyembuhan Luka pada Ikan Nila Pasca Infeksi Bakteri Aeromonas hydrophilla Ulangan Perlakuan

\begin{tabular}{ccccc} 
& $\mathrm{A}(\% /$ hari $)$ & $\mathrm{B}(\% /$ hari $)$ & $\mathrm{C}(\% /$ hari $)$ & $\mathrm{D}(\% /$ hari $)$ \\
\hline \hline 1 & 0.00 & 0.07 & 0.62 & 0.50 \\
2 & 0.00 & 0.53 & 0.80 & 0.58 \\
3 & 0.00 & 0.20 & 0.78 & 0.48 \\
Rerata & 0.00 & 0.27 & 0.73 & 0.52 \\
\hline
\end{tabular}

Berdasarkan tabel 1 terlihat nilai penyembuhan luka pada masing-masing perlakuan dari yang tertinggi hingga terendah adalah perlakuan $\mathrm{C}(100 \mathrm{ppm})$ sebesar 0,73\%/hari, perlakuaan D (150 ppm) sebesar 0,52 $\% /$ hari, perlakuan B (50 ppm) sebesar 0,27 \%/hari dan perlakuan A $0,00 \% /$ hari. Penyembuhan luka yang terjadi pada perlakuan $\mathrm{C}$ lebih baik dibanding perlakuan lain hal ini diduga karena dosis 100 ppm mampu mengobati luka pada ikan secara optimal dibanding perlakuan D dan B. Pada kontrol selama masa pengamatan belum terlihat adanya penyembuhan. Bahkan dibeberapa perlakuan terjadi kematian total yaitu pada perlakuan A1 dan A2. Kematian ini diduga karena ikan pasca infeksi mengalami penurunan daya tahan tubuh sehingga mengalami stress dan bakteri akan mudah menyerang ikan uji.

\subsection{Kelangsungan Hidup}

Berdasarkan hasil penelitiaan diperoleh nilai kelangsungan hidup pada ikan nila (Oreochromis niloticus) pasca infeksi tersaji pada tabel 2. Rerata nilai kelangsungan hidup tertinggi terdapat pada perlakuan $\mathrm{C}$ $(83,33 \%)$, kemudian perlakuan B $(66,66 \%)$, perlakuan D $(60 \%)$ dan perlakuan A (40\%).Tingginya rerata kelangsungan hidup pada perlakuan $\mathrm{C}$ diduga karena pada dosis 100 ppm, ikan sudah mampu memanfaatkan ekstrak tersebut sebagai antibakteri pada tubuhnya. Perlakuaan $\mathrm{C}$ sangat berbeda nyata dengan perlakuaan A, hal ini menunjukan bahwa pemeberian ekstran buah lambai-lambai memberikan pengaruh yang nyata terhadap kekebalan tubuh ikan sehingga proses pengobatan pada ikan dapar berjalan secara maksimal
Tabel 2. Rerata Kelangsungan Hidup Ikan Nila

\begin{tabular}{ccc}
\hline No & Perlakuan & $\begin{array}{c}\text { Tingkat Kelangsungan Hidup } \\
(\%)\end{array}$ \\
\hline 1 & A & 40 \\
2 & B & 60 \\
3 & C & 83.33 \\
4 & D & 66.66 \\
\hline
\end{tabular}

\subsection{Respon Ikan Terhadap Pakan}

Respon pakan yang ditunjukan oleh ikan nila (Oreochromis niloticus) pasca injeksi bakteri Aeromonas hydrophila dapat dilihat pada Tabel 3. Pengamatan pada hari 1 sampai ke-5 tidak menunjukan adanya respon terhadap pakan. Respon ikan terhadap pakan terlihat normal pada hari ke 6 yaitu pada perlakuan $\mathrm{C}$ sedangkan perlakuan $\mathrm{A}, \mathrm{B}$ dan $\mathrm{C}$ respon pakan masih kurang. Pada hari $1-4$ secara keseluruhan ikan uji tidak merespon pakan yang diberikan hal ini diduga karena ikan masih dalam keadaan stress pasca injeksi sehingga mempengaruhi nafsu makan ikan.

Menurut Irianto, 2005 dalam Yuhana, dkk 2010 stress merupakan suatu keadaan saat suatu hewan tidak mampu mengatur kondisi fisiologis yang normal karena berbagai faktor merugikan yang mempengaruhi kesehatannya.salah satu reaksi ikan saat stress adalah menurunnya nafsu makan. Pada hari ke 5 perkuan B, C dan D ikan sudah mulai merespon pakan yang diberikan, hal ini diduga karena ikan sudah mulai mengalami proses penyembuhan pada luka sehingga nafsu makan ikan berangsur-angsur mulai membaik dan kembali normal. Semakin baik respon pakan pada ikan maka semakin cepat pula terjadi proses penyembuhan (Yuhana, dkk., 2008

Tabel 3. Respon ikan Terhadap Pakan Pasca Injeksi Bakteri Aeromonas hydrophila

\begin{tabular}{|c|c|c|c|c|c|c|c|c|c|c|c|c|}
\hline \multicolumn{13}{|c|}{ Konsentrasi Ekstrak Lambai-lambai } \\
\hline \multirow{3}{*}{$\begin{array}{c}\text { Pengamatan } \\
\text { Hari ke - }\end{array}$} & \multicolumn{12}{|c|}{$\begin{array}{l}\text { Perlakuan } \\
\end{array}$} \\
\hline & \multicolumn{3}{|c|}{ A } & \multicolumn{3}{|c|}{$\mathrm{B}$} & \multicolumn{3}{|c|}{$\mathrm{C}$} & \multicolumn{3}{|c|}{$\mathrm{D}$} \\
\hline & 1 & 2 & 3 & 1 & 2 & 3 & 1 & 2 & 3 & 1 & 2 & 3 \\
\hline 1 & - & - & - & - & - & - & - & - & - & - & - & - \\
\hline 2 & - & - & - & - & - & - & - & - & - & - & - & - \\
\hline 3 & - & - & - & - & - & - & - & - & - & - & - & - \\
\hline 4 & - & - & - & - & - & - & - & - & - & - & - & - \\
\hline 5 & - & - & - & - & + & - & + & + & - & + & + & + \\
\hline 6 & - & + & - & + & + & + & ++ & ++ & + & + & + & + \\
\hline 7 & + & + & + & + & + & + & ++ & ++ & ++ & ++ & + & ++ \\
\hline 8 & + & + & + & + & + & ++ & ++ & ++ & ++ & ++ & ++ & ++ \\
\hline 9 & + & + & + & ++ & ++ & ++ & ++ & ++ & ++ & ++ & ++ & ++ \\
\hline 10 & + & + & + & ++ & ++ & ++ & ++ & ++ & ++ & ++ & ++ & ++ \\
\hline 11 & + & ב & + & ++ & ++ & ++ & ++ & ++ & ++ & ++ & ++ & ++ \\
\hline 12 & + & & + & ++ & ++ & ++ & ++ & ++ & ++ & ++ & ++ & ++ \\
\hline 13 & בם & & + & ++ & ++ & ++ & ++ & ++ & ++ & ++ & ++ & ++ \\
\hline 14 & & & + & ++ & ++ & ++ & ++ & ++ & ++ & ++ & ++ & ++ \\
\hline
\end{tabular}


$\begin{array}{lllll}\text { Keterangan : } & (-) & \text { Respon pakan tidak ada } & (++) & \begin{array}{l}\text { Respon terhadap pakan normal } \\ \text { kematiaan } 100 \%\end{array} \\ & (+) & \text { Respon pakan kurang } & \text { (5 }\end{array}$

Hasil pengamatan respon ikan nila (Oreochromis niloticus) terhadap kejutan pasca injeksi Aeromonas hydrophila dapat dilihat pada Tabel 4. Uji respon ikan terhadap kejutan dilakukan dengan cara mengetuk dinding media pemeliharaan pada setiap perlakuan. Berdasarkan Tabel 3 respon ikan terhadap kejutan menunjukan bahwa benih ikan nila (Oreochromis niloticus) untuk semua perlakuan menunjukan tidak adanya respon terhadap kejutan sampai hari ke 4. Tidak adanya respon ikan diduga karena adanya peradangan pada daerah sekitar suntikan. Seekor ikan yang tidak sehat bisa lebih lambat atau lebih cepat dari biasanya (Nabib dan Pasaribu, 1989 dalam Yuhana, dkk 2008). Respon kejutan kembali normal terlihat pada hari ke 5 yaitupada perlakuan C sedangkan perlakuan A,B dan D masih kurang dan bahkan sudah ada beberapa perlakuan yang sudah mengalami kematian setelah beberapa hari pasca injeksi bakteri Aeromonas hydrophila.

Tabel 4. Respon Ikan Nila (Oreochromis niloticus) Terhadap Kejutan

\begin{tabular}{|c|c|c|c|c|c|c|c|c|c|c|c|c|}
\hline \multicolumn{13}{|c|}{ Konsentrasi Ekstrak Lambai-lambai } \\
\hline \multirow{3}{*}{$\begin{array}{c}\text { Pengamatan } \\
\text { Hari ke - }\end{array}$} & \multicolumn{12}{|c|}{$\begin{array}{ll} & \text { Perlakuan } \\
\end{array}$} \\
\hline & \multicolumn{3}{|c|}{$\mathbf{A}$} & \multicolumn{3}{|c|}{$\mathbf{B}$} & \multicolumn{3}{|c|}{$\mathrm{C}$} & \multicolumn{3}{|c|}{$\mathbf{D}$} \\
\hline & 1 & 2 & 3 & 1 & 2 & 3 & 1 & 2 & 3 & 1 & 2 & 3 \\
\hline 1 & - & - & - & - & - & - & - & - & - & - & - & - \\
\hline 2 & - & - & - & - & - & - & - & - & - & - & - & - \\
\hline 3 & - & - & - & - & - & - & - & - & - & - & - & - \\
\hline 4 & - & - & - & - & - & - & - & - & - & - & - & - \\
\hline 5 & - & - & - & - & + & + & ++ & ++ & ++ & + & + & ++ \\
\hline 6 & + & + & + & + & + & + & ++ & ++ & ++ & + & ++ & ++ \\
\hline 7 & + & + & + & + & + & + & ++ & ++ & ++ & + & ++ & ++ \\
\hline 8 & + & + & + & + & + & + & ++ & ++ & ++ & ++ & ++ & ++ \\
\hline 9 & + & + & + & ++ & + & + & ++ & ++ & ++ & ++ & ++ & ++ \\
\hline 10 & + & + & + & ++ & ++ & ++ & ++ & ++ & ++ & ++ & ++ & ++ \\
\hline 11 & + & ש & + & ++ & ++ & ++ & ++ & ++ & ++ & ++ & ++ & ++ \\
\hline 12 & + & & + & ++ & ++ & ++ & ++ & ++ & ++ & ++ & ++ & ++ \\
\hline 13 & 담 & & + & ++ & ++ & ++ & ++ & ++ & ++ & ++ & ++ & ++ \\
\hline 14 & & & + & ++ & ++ & ++ & ++ & ++ & ++ & ++ & ++ & ++ \\
\hline Keterangan : & $(-)$ & Res & tid & & & & Resp & no & & & & \\
\hline & $(+)$ & Res & $\mathrm{ku}$ & & & & kem & in & $\%$ & & & \\
\hline
\end{tabular}

\subsection{Kualitas Air}

Selama masa pemeliharaan dilakukan pengukuran kualitas air pada awal dan akhir penelitiaan. Pengamatan meliputi suhu, $\mathrm{pH}$, DO dan $\mathrm{NH}_{3}$. Data kisaran kualitas air selama masa pemeliharaan dapat dilihat pada tabel 5. Berdasarkan Tabel 5 kondisi perairan pada media perairan masih dalam kondisi yang masih bisa ditolerir oleh ikan. Suhu pada media pemeliharaan berkisar antara 26,9 - 30oC. pada kisaran ini ikan masih mampu dirolerir oleh ikan nila(Oreochromis niloticus), pendapat ini didukung oleh Alfia, dkk (2013) suhu optimal untuk benih ikan nila antara $25-30^{\circ} \mathrm{C}, \mathrm{pH}$ air pada media pemeliharaan berkisar antara 7,50-7,78. $\mathrm{pH}$ ini masih termasuk $\mathrm{pH}$ yang baik bagi ikan nila (Oreochoromis niloticus) dimana menurut Khairuman dan Amri 2012 $\mathrm{pH}$ yang baik bagi ikan nila masih dalam kondisi yang masih bisa ditolerir oleh ikan sehingga dapat disimpulkan bahwa kematiaan yang terjadi pada ikan uji adalah akibat infeksi bakteri Aeromonas hydrophyla. adalah 5-8,9. Nilai DO berkisar antara 1,02-1,25 ppm, CO2berkisar antara 0,79-0,89 ppm dan amoniak Kualitas Air pada masa pemeliharaan masih dapat ditolerir oleh ikan uji. pada media pemeliharaan berkisar antara $0,01-0,02 \mathrm{ppm}$.
Tabel 5. Kisaran Kualitas Air Selama Masa Pemeliharaan

\begin{tabular}{clcc}
\hline No & \multicolumn{1}{c}{ Parameter } & Nilai & $\begin{array}{c}\text { Satua } \\
\text { n }\end{array}$ \\
\hline 1 & Suhu & $26,9-30$ & ${ }^{\circ} \mathrm{C}$ \\
2 & pH & $7,50-7,78$ & \\
3 & Oksigen Terlarut (DO) & $1,02-1,25$ & $\mathrm{Mg} / 1$ \\
4 & Karbondioksida (CO2) & $0,79-0,89$ & $\mathrm{Mg} / 1$ \\
5 & Amoniak (NH3) & $0,01-0,02$ & $\mathrm{Mg} / 1$ \\
\hline
\end{tabular}

\section{KESIMPULAN}

Berdasarkan hasil penelitiaan yang dilakukan maka dapat disimpulkan bahwa, ekstrak lambai-lambai dapat digunakan untuk mengobati serangan bakteri Aeromomas hydrophyla. Dosis yang efektif untuk mengobati penyakit akibat serangan bakteri Aeromonas hydrophyla adalah 100 ppm. Kualitas Air pada masa pemeliharaan masih dapat ditolerir oleh ikan uji.

\section{SARAN}

Adanya penelitiaan lanjutan tentang penggunakaan ekstrak buah lambai-lambai untuk mengobati penyakit ikan lainnya, tidak hanya serangan bakteri Aeromonas hydrophila dan dengan jenis ikan uji yang berbeda

\section{DAFTAR PUSTAKA}


Aisyah. 2013 Pengaruh Variasi Iklim Terhadap Konsentrasi Senyawa Nitrogen di Wilayah Keramba Jaring Apung, Waduk Cirata, Jawa Barat Prosiding Pertemuaan Ilmiah Tahuna MLI I, Cibinong

Alfia, Averus Rizki., dkk. 2013. Pengaruh kepadatan yang berbeda terhadap kelulushidupan dan pertumbuhan ikan nila (Oreochromis nilotica) pada sistem resirkulasi dengan filter bioball. Program studi budidaya perairan jurusan perikanan dan ilmu kelautan universitas diponogoro.

Khairuman dan Amri. 2012. Pembesaran Nila di Kolam Air Deras. Cetakan Pertama. PT. Agro Media Pustaka. Jakarta.

Khordi. M. G. H. 2004. Penanggulangan Hama dan Penyakit Ikan.. PT. Bina Adiaksara dan PT. Rineka Cipta. Jakarta.

Kurniawan, D. 2010. Efektifitas Campuran Tepung Meniran Phyllanthus niruri dan Bawang Putih Allium sativum Dalam Pakan Untuk Pencegahan Infeksi Bakteri Aeromonas hydrophyla Pada Ikan Lele Dumbo Clarias sp. Skripsi. Fakultas Perikanan dan Ilmu Kelautan. ITB. Bogor
Sanoesi. 2008. Penggunaan Ekstrak Daun Pepaya (Carica papaya Linn) Terhadap Jumlah Sel Makrofag Pada Ikan Mas Cyprinus carpio L) Yang Terinfeksi Bakteri Aeromonas hydrophyla. Jurnal Penelitiaan Perikanan Indonesia Vol. 11 No. 2

Sartika, Y. 2011. Efektivitas Fitoparmaka Dalam Pakan Untuk Pencegahan Infeksi Bakteri Aeromonas hydrophila Pada Ikan Lele Dumbo Clarias sp.(Skripsi). Fakultas Perikanan dan Ilmu Kelautan dan Perikanan. Institut Pertanian Bogor. Bogor.

Yuhana, M. 2008. Pemanfaatan Ekstraksi Bawang Putih Allium sativum untuk Pencegahan dan Pengobatan Pada Ikan Patin Pangasionodon hypophtalmus Yang Diinfeksi Aeromonas hydrophyla. Departemen Budidaya Perairan, Fakultas Perikanan dan Ilmu Kelautan, IPB. Bogor 